\title{
Bats in a restinga area in Sergipe, Northeastern Brazil
}

\author{
Rayanna Hellem Santos Bezerra ${ }^{1,2}$ \& Adriana Bocchiglieri ${ }^{1,3}$ \\ 1 Universidade Federal de Sergipe (UFS), Centro de Ciências Biológicas e da Saúde (CCBS), Departamento de Ecologia (DECO), \\ Laboratório de Mastozoologia, Programa de Pós-Graduação em Ecologia e Conservação. São Cristóvão, SE, Brasil. \\ ${ }^{2}$ ORCID: http://orcid.org/0000-0001-7904-7642. E-mail: rayhellem@hotmail.com \\ 3 ORCID: http://orcid.org/0000-0002-6911-1070. E-mail: adriblue@hotmail.com
}

\begin{abstract}
There is little known about the bats of the Brazilian restinga as most studies have concentrated on the country's south and southeast regions. In Sergipe, Northeastern Brazil, the only study previously carried out registered 17 species in different restinga habitats. Thus, this study aimed to characterize the bat community in a restinga area in Sergipe and update the list of species that occur in the area. The study was carried out in the Caju Private Natural Heritage Reserve, on the south coast of the state of Sergipe. Monthly campaigns were carried out from 0ctober 2016 to September 2017 over two consecutive nights and alternating between two sites to capture the bats. We captured Bats using 10 mist nets that remained open between 6:00 p.m. and 12:00 p.m. We determined the abundance and trophic guilds of the captured species. In addition, we obtained the occurrence frequency degree through the Constancy Index. We captured 457 individuals distributed over 13 species and two families, where three species represented a new record for the locality. The family Phyllostomidae was the richest and most abundant. Most species were frugivorous (61.5\%). According to the Constancy Index, only four species were considered common. Using Jackknife 1 estimator, we estimated 14.83 species for the area, indicating that the richness obtained in this study corresponds to $87.6 \%$ of this estimate. This study resulted in an $17.6 \%$ increase in bat richness known for the area. The high representativeness of the Phyllostomidae family may be related to the capture method used. The predominance of frugivores bats in this study may be associated with the presence of many fruit trees in the area. The low occurrence of species considered common is often reported and can be explained by the species' trophic specializations and by the sampling methods. Considering the scarcity of studies in restinga areas in Northeastern Brazil, this work becomes important for the knowledge of the bats in this environment, especially for Sergipe.
\end{abstract}

Keywords. Chiroptera; Community; Inventory; Northeastern Brazil; Phyllostomidae.

\section{INTRODUCTION}

Restinga environments are characterized by long strips of sandy marine deposits, with poor soils, a high degree of salinity, high temperature, and intense luminosity (Hay et al., 1981). This environment presents vegetation that varies from herbaceous formations, shrubs, and denser forests, as it moves away from the sea line, whose canopy does not exceed $20 \mathrm{~m}$ in height (Silva, 1999; IBGE, 2012). It is characterized as a vegetation subset of the Atlantic Forest (Cerqueira et al., 1990) and, because it is generally close to forest areas, it contains important breeding, feeding, and shelter sites for fauna (Bôlla et al., 2017). In general, the biological composition in restingas is considered a subset of adjacent areas (Rizzini, 1997), and it is one of the least known environments in the Atlantic Forest biome (Rocha et al., 2005; Oprea et al., 2009).

For Chiroptera, studies have revealed that there is not a restricted fauna to restinga environ- ments in Brazil, with the occurrence of generalist and common species, which form a subset of species of the adjacent forest areas (Cerqueira, 2010). Despite the increase in the number of studies with bats in this environment in recent years (Bôlla et al., 2017), most of these are concentrated in the south and southeast regions of the country in the states of Rio de Janeiro (Cerqueira et al., 1990; Pessôa et al., 2010; Luz et al., 2011; Gomes et al., 2016), Espírito Santo (Luz et al., 2009; Oprea et al., 2009), Santa Catarina (Carvalho et al., 2009; Bôlla et al., 2017), and Paraná (Fogaça \& Reis, 2008). In the northeast of the country, studies with this group in restingas have only been carried out in Paraíba (Campos et al., 2018), Rio Grande do Norte (Soares et al., 2018), and Sergipe (Rocha et al., 2017).

Some of these studies corresponded to a rapid survey with a small sampling effort in different habitats (Luz et al., 2009; Gomes et al., 2016; Rocha et al., 2017; Soares et al., 2018), and most of them revealed a low efficiency of bat capture in the rest- 
inga areas (e.g., Luz et al., 2009, 2011; Oprea et al., 2009; Nogueira et al., 2010; Gomes et al., 2016). Although the majority of species registered in this environment are generalist, the limitation of resources such as food and shelter in the restinga influences the lowest rates recorded (Nogueira et al., 2010), reflecting the lower densities for the group (Luz et al., 2011).

In Sergipe, Northeastern Brazil, Rocha et al. (2017, 2018a) recorded 17 species in a rapid survey conducted in different habitats of the restinga area in the south of the state. This study presents an update of this inventory and aimed to characterize the richness and composition of bat species in this area during a year.

\section{MATERIAL AND METHODS}

\section{Study area}

This work was conducted at the Caju Private Natural Heritage Reserve (RPPN do Caju; $11^{\circ} 07^{\prime} \mathrm{S}$; $37^{\circ} 11^{\prime} \mathrm{W}$ ) located on the south coast of the state of Sergipe, in the municipality of Itaporanga d'Ajuda (Braghini \& Vilar, 2013a; Fig. 1). This area, with approximately $763 \mathrm{ha}$, corresponds to a remnant of the Atlantic Forest associated with restinga, mangrove, and apicum environments and property of EMBRAPA Tabuleiros Costeiros (Braghini \& Vilar, 2013b; EMBRAPA, 2013).

The surrounding areas are characterized by shrimp farming, plant extraction, real estate expansion, and tourism, which negatively influences local conservation (Braghini \& Vilar, 2013b; EMBRAPA, 2013). The area has a megathermic tropical climate (Alvares et al., 2013) with an accumulated rainfall during the study period of 1,596.5 mm and greater rainfall between April and September (EMBRAPA, unpublished data).

Two sites in restinga environments $600 \mathrm{~m}$ apart (Fig. 1) were studied. Site 1 is characterized by the presence of dense vegetation with a closed understory and the presence of a temporary pond. Site 2 has a more open understory, bordered by a plantation of Hancornia speciosa Gomes (mangabeira; Fig. 2; Bezerra \& Bocchiglieri, 2018).

\section{Data collection and analysis}

We carried out the campaigns monthly, for two consecutive nights, from October 2016 to September 2017, alternating between the two sites. We used ten mist nets $(9 \times 3 \mathrm{~m}$, mesh $20 \mathrm{~mm})$. They remained open between 6:00 p.m. and 12:00 p.m. and we inspected them at 30-minute intervals. We identified each captured bat based on Díaz et al. (2016) and Peracchi \& Lima (2017), using specialized keys when necessary. We marked and released the Bats at the same capture site according to the SISBIO Research and Collection License № 54957-1.

Sampling effort was determined following Straube \& Bianconi (2002). We determined each captured species' abundance and classified them based on their trophic guilds, according to Kalko et al. (1996). Through the

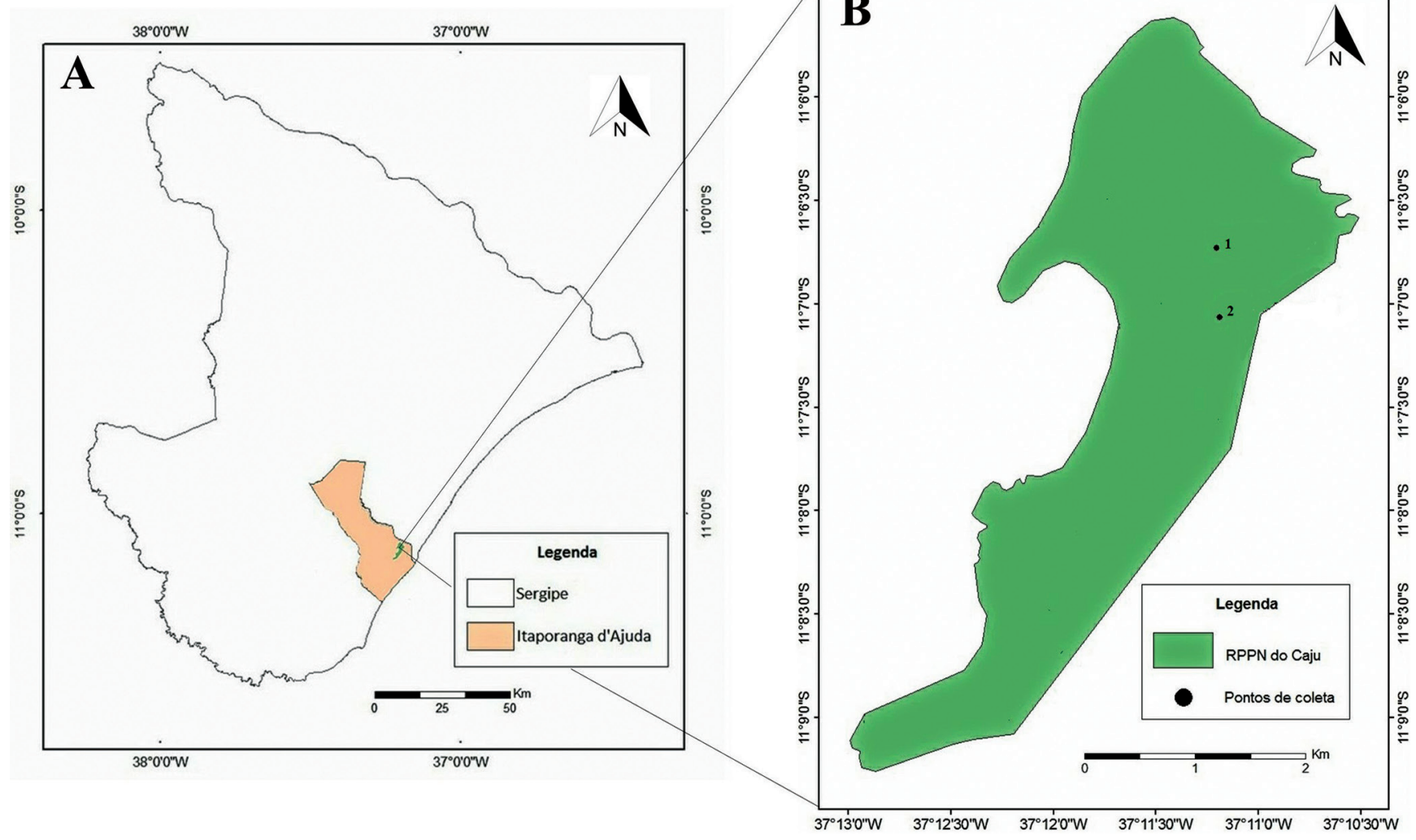

Figure 1. Location of the study area. (A) The state of Sergipe with a highlight on the municipality of Itaporanga d'Ajuda; (B) Caju Private Natural Heritage Reserve with an indication of the campaign sites (sites 1 and 2). 

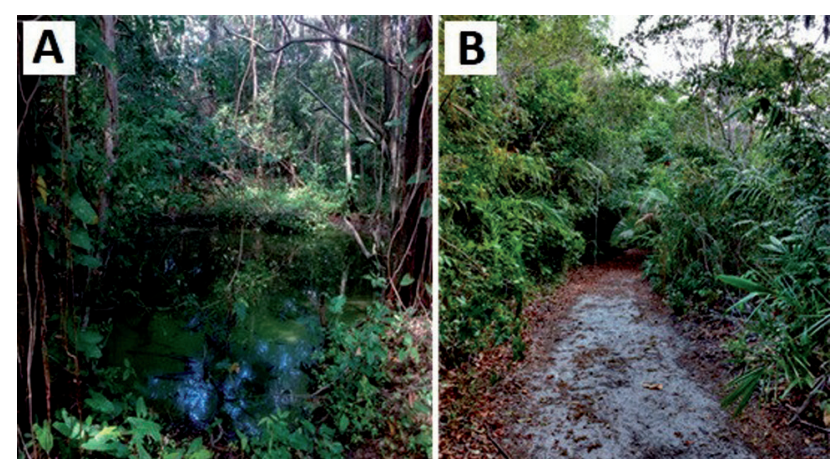

Figure 2. Campaign sites used to capture bats in the Caju Private Natural Heritage Reserve, Sergipe. (A) Site 1 and (B) Site 2.

Constancy Index (C), we categorized species as frequent ( $C \geq 50 \%)$, uncommon $(25 \leq C<50 \%)$, and rare $(C<25 \%)$, according to Silveira-Neto et al. (1976).

The richness was estimated using the EstimateSWin 8.2 program (Colwell, 2011), the non-parametric estimator that presented the less accumulated standard deviation (Jackknife 1), and through the construction of 10,000 accumulation curves of species with an increase in the sampling effort.

\section{RESULTS}

With a sampling effort of $35,316 \mathrm{~m}^{2}$.h, we had 490 captures, from 457 individuals belonging to 13 species and distributed among the families of Phyllostomidae $(S=11)$ and Vespertilionidae $(S=2)$. Of the species captured, Myotis riparius Handley 1960, Phyllostomus discolor (Wagner, 1843), and Chiroderma doriae Thomas, 1891, represented new records for the locality, totaling 20 species of bats in the RPPN do Caju.

Regarding the trophic guilds, we captured frugivorous (61.5\%), insectivorous (23.1\%), nectarivorous, and omnivorous species (both $7.7 \%$ each; Table 1 ). The Phyllostomidae family was the richest and most abundant, with $84.6 \%$ of the species and $99 \%$ of the captured

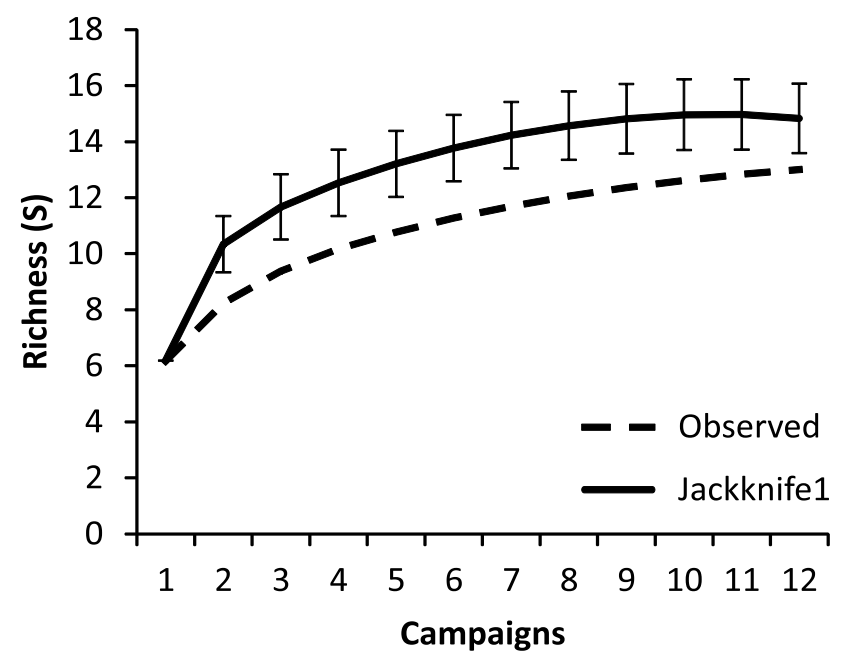

Figure 3. Accumulation curves of bat species observed (dashed line) and estimated (continuous line) during campaigns carried out in the Caju Private Natural Heritage Reserve, Sergipe. Vertical lines represent the standard deviation.
Table 1. Bats species recorded at the Caju Private Natural Heritage Reserve (RPPN do Caju), Sergipe, Northeastern Brazil. $\mathrm{N}=$ number of individuals (recapture) and $\mathrm{C}=$ Constance index. ${ }^{*}=$ New record for locality.

\begin{tabular}{|c|c|c|c|}
\hline Species & $\begin{array}{c}\mathrm{N} \\
\text { (recapture) }\end{array}$ & C & $\begin{array}{l}\text { Trophic } \\
\text { guild }\end{array}$ \\
\hline \multicolumn{4}{|l|}{ Family Phyllostomidae } \\
\hline \multicolumn{4}{|l|}{ Subfamily Carolliinae } \\
\hline Carollia perspicillata (Linnaeus 1758) & $213(31)$ & 95.4 & Frugivore \\
\hline \multicolumn{4}{|l|}{ Subfamily Stenodermatinae } \\
\hline Artibeus lituratus (0lfers 1818) & 69 & 86.3 & Frugivore \\
\hline Artibeus obscurus (Schinz 1821) & 9 & 27.2 & Frugivore \\
\hline Artibeus planirostris (Spix 1823) & $61(1)$ & 63.6 & Frugivore \\
\hline Chiroderma doriae Thomas $1891^{*}$ & 1 & 4.5 & Frugivore \\
\hline Dermanura cinerea Gervais 1856 & $59(1)$ & 68.1 & Frugivore \\
\hline Platyrrhinus lineatus (É. Geoffroy 1810) & 4 & 18.1 & Frugivore \\
\hline Sturnira lilum (É. Geoffroy 1810) & 7 & 9.0 & Frugivore \\
\hline \multicolumn{4}{|l|}{ Subfamily Glossophaginae } \\
\hline Glossophaga soricina (Pallas 1766) & 17 & 40.9 & Nectarivore \\
\hline \multicolumn{4}{|l|}{ Subfamily Phyllostominae } \\
\hline Lophostoma brasiliense Peters 1867 & 12 & 40.9 & Insectivore \\
\hline Phyllostomus discolor Wagner $1843^{*}$ & 1 & 4.5 & Omnivore \\
\hline \multicolumn{4}{|l|}{ Family Vespertilionidae } \\
\hline Myotis lavali Moratelli, Peracchi, Dias e De Oliveira 2011 & 2 & 9.0 & Insectivore \\
\hline Myotis riparius Handley $1960^{*}$ & 2 & 9.0 & Insectivore \\
\hline Total & $457(33)$ & & \\
\hline
\end{tabular}

individuals. The most abundant species were Carollia perspicillata (Linnaeus, 1758) ( $\mathrm{N}=213,46.6 \%)$, Artibeus lituratus (Olfers, 1818) ( $\mathrm{N}=69,15.1 \%)$, A. planirostris (Spix, 1823) ( $\mathrm{N}=61,13.3 \%)$, and Dermanura cinerea Gervais, 1856 ( $N=59,12.9 \%$; Table 1). According to the Constancy Index, we considered these species frequent. In contrast, we considered Glossophaga soricina (Pallas, 1766), Lophostoma brasiliense Peters, 1867, and A. obscurus (Schinz 1821) uncommon, and we classified the others as rare (Table 1).

Based on Jackknife 1, we estimated $14.83 \pm 1.24$ species from the sampling effort spent (Fig. 3), indicating that the richness recorded in this study $(S=13)$ corresponded to $87.6 \%$ of the estimate for the area.

\section{DISCUSSION}

In the RPPN do Caju, 17 species of bats were known (Rocha et al., 2017, 2018a), of which 10 (62.5\%) we captured in this study. The previous record of $M$. nigricans (Schinz 1821) presented by these authors corresponded to M. lavali, also captured in this study. There was an addition of three species to the locality, which resulted in an $17.6 \%$ increase in bat richness recorded in the area, for a total of 20 species.

The richness observed in restinga environments varied from 2 (Cerqueira et al., 1990) to 17 species (Luz et al., 2009). This difference was due to different sampling efforts, that varied between 1,440 $\mathrm{m}^{2}$.h ( 3 species; Nogueira et al., 2010) and 63,926 $\mathrm{m}^{2} . \mathrm{h}$ (13 species; Bôlla et al., 2017), and capture methods at each location. The lower richness found in this study, when compared to that previously carried out in the RPPN do Caju, may be 
related to the change in the location of the mist nets during sampling, resulting in the record of more species by Rocha et al. (2017). Likewise, Luz et al. $(2009,2011)$ and Oprea et al. (2009), despite the different sampling efforts and low capture rate, recorded between 14 and 17 species in the restinga areas in Southeastern Brazil as a reflection of the greater variety of sampled environments.

The predominance of frugivores bats in this study may be associated with the presence of many fruit trees in the area (EMBRAPA, 2013; personal observation) and the fact that this guild is well represented in neotropical environments (Nogueira et al., 2010). In addition, frugivore bats of the Phyllostomidae family are predominant in studies with mist nets in the Neotropical region (Bergallo et al., 2003; Nogueira et al., 2010). The same pattern was also observed in other restinga areas (Carvalho et al., 2009; Oprea et al., 2009; Luz et al., 2011; Soares et al., 2018) as a reflection of the sampling method and the availability of fruits in the areas.

Carollia perspicillata, A. lituratus, A. planirostris, and $D$. cinerea were the most captured species in this study, being abundant in restinga areas (Oprea et al., 2009; Nogueira et al., 2010; Luz et al., 2011; Gomes et al., 2016; Soares et al., 2018). These species occur in a variety of habitats, from more structured forests to degraded areas and plantations (Bernard, 2002; Passos et al., 2003), and have high ecological flexibility because they are able to explore a wide variety of resources (Mikich, 2002; Passos et al., 2003).

In the RPPN do Caju, these four species (30.7\% of the total species captured) were also considered frequent and the most abundant. The capture of bats in Neotropical environments using mist nets is generally composed of a few common species and many rare species (Kalko \& Handley, 2001). This low frequency of some species may be related to the trophic specialization of the species or sampling methods (Kalko \& Handley, 2001). Thus, it is important to consider the capture method used that may have influenced the abundance of the species (Simmons \& Voss, 1998; Larsen et al., 2007).

Sampling in different environments and with complementary methodologies, such as active search and ultrasound detectors, can contribute to the increase in richness (Esbérard \& Bergallo, 2008; Carvalho et al., 2009; Gomes et al., 2016) from a high number of captures (Bergallo et al., 2003). In the RPPN do Caju, there is an expectation of greater richness since Rocha et al. (2017) registered representatives of the Molossidae and Emballonuridae families through the use of mist nets close to shelters. Thus, a greater sampling effort with the use of additional collection methods in different environments may reflect an increase in the local number of species.

Considering the scarcity of studies in restinga areas in Northeastern Brazil, this work becomes important for the knowledge about the chiropterofauna in this environment, especially for the state of Sergipe where studies related to the characterization of this group's community are still considered incipient in the region (Mikalauskas, 2005; Rocha et al., 2010, 2015, 2018b; Brito \& Bocchiglieri, 2012).

\section{ACKNOWLEDGMENTS}

This study was financed in part by the Coordenação de Aperfeiçoamento de Pessoal de Nível Superior - Brasil (CAPES) - Finance Code 001. We are grateful to EMBRAPA Tabuleiros Costeiros and Universidade Federal de Sergipe (UFS) for logistical support, Fundação de Apoio à Pesquisa e Inovação Tecnológica do Estado de Sergipe (FAPITEC) (\# 019.203.01181/2011-2); and CAPES for financial support $(2417 / 2013 ; 1941 / 2017)$, and the students of the Laboratório de Mastozoologia/UFS for helping us in the field campaigns.

\section{AUTHORS' CONTRIBUTIONS}

R.H.S.B.: Methodology, Validation, Formal analysis, Investigation, Writing - Original Draft. A.B.: Conceptualization, Methodology, Formal analysis, Resources, Writing - Review \& Editing, Supervision. All Authors actively participated of the results discussion and reviewed and approved the final version of the paper.

\section{REFERENCES}

Alvares, C.A.; Stape, J.L.; Sentelhas, P.C.; Gonçalves, J.L.M. \& Sparovek, G. 2013. Köppen's climate classification map for Brazil. Meteorologische Zeitschrift, 22(6): 711-728.

Bergallo, H.G.; Esbérard, C.E.L.; Mello, M.A.R.; Lins, V.; Mangolin, R.; Melo, G.G.S. \& Baptista, M. 2003. Bat species richness in Atlantic Forest: what is the minimum sampling effort? Biotropica, 35(2): 278-288.

Bernard, E. 2002. Diet, activity and reproduction of bats species (Mammalia, (hiroptera) in Central Amazonia, Brazil. Revista Brasileira de Zoologia, 19: 173-188.

Bezerra, R.H.S. \& Bocchiglieri, A. 2018. Association of ectoparasites (Diptera and Acari) on bats (Mammalia) in a restinga habitat in northeastern Brazil. Parasitology Research, 117(11): 3413-3420.

Bôlla, D.A.S.; Carvalho, F.; Miranda, J.M.D.; Zocche, J.J.; Harter-Marques, B.; Martins, R.; Pavei, D.D. \& Luzzietti, M.M. 2017. Assembléia de morcegos (Mammalia: Chiroptera) em ambiente de Restinga alterada no sul do Brasil. Neotropical Biology \& Conservation, 12(2): 135-142.

Braghini, C.R. \& Vilar, J.W.C. 2013a. Dilemas e desafios da gestão territorial da RPPN do Caju, litoral de Itaporanga d'Ajuda, Sergipe. OLAM - Ciência \& Tecnologia, 1(2): 298-323.

Braghini, C.R. \& Vilar, J.W.C. 2013b. Gestão territorial de áreas protegidas no litoral sergipano: primeiras incursões. Revista do Grupo de Pesquisa "Processos Identitários e Poder", 1: 1-14.

Brito, D.V. \& Bocchiglieri, A. 2012. Comunidade de morcegos (Mammalia, Chiroptera) no Refúgio de Vida Silvestre Mata do Junco, Sergipe, nordeste do Brasil. Biota Neotropica, 12: 1-9.

Campos, B.A.T.P.; Feijó, A.; Brennand, P.G.G. \& Percequillo, A.R. 2018. Mammals of a restinga forest in Mataraca, Paraíba, northeastern Brazil, and its affinities to restinga areas in Brazil. Biota Neotropica, 18(1): 1-9, e20170392.

Carvalho, F.; Zocche, J.J. \& Mendonça, R.A. 2009. Morcegos (Mammalia, (hiroptera) em restinga no município de Jaguaruna, sul de Santa Catarina, Brasil. Biotemas, 22(3): 193-201. 
Cerqueira, R. 2010. Mamíferos e restingas. In: Pessôa, L.M.; Tavares, W.C. \& Siciliano, S. Mamíferos das Restingas e Manguezais do Brasil. Rio de Janeiro, Sociedade Brasileira de Mastozoologia. p. 11-16.

Cerqueira, R.; Fernandez, F.A.S. \& Quintela, M.F.S. 1990. Mamíferos da Restinga de Barra de Maricá, Rio de Janeiro. Papéis Avulsos de Zoologia, 37(9): 141-157.

Colwell, R.K. 2011. Estimates 9.1: statistical estimation of species richness and shared species from samples. Available: http://viceroy.eeb.uconn.edu/ estimates.

Díaz, M.M.; Solari, S.; Aguirre, L.F.; Aguiar, L.M.S. \& Barquez, R.M. 2016. Clave de identificação de los murcielagos de Sudamerica. Programa de Conservación de los murciélagos de Argentina. 162p. (Publicación especial № 2).

Empresa Brasileira de Pesquisa Agropecuária (EMBRAPA). 2013. Plano de Manejo. Reserva Particular do Patrimônio Natural (RPPN) do Caju. Sergipe, EMBRAPA Tabuleiros Costeiros.

Esbérard, C.E.L. \& Bergallo, H.G. 2008. Influência do esforço amostral na riqueza de espécies de morcegos no sudeste do Brasil. Revista Brasileira de Zoologia, 25: 67-73.

Fogaça, F.N.O. \& Reis, N.R. 2008. Análise comparativa da quiropterofauna da restinga paranaense e adjacências. In: Reis, N.R.; Peracchi, A.L. \& Santos, G.A.S.D. Ecologia de Morcegos. Londrina, Technical Books Editora. p. 87-95.

Gomes, L.A.C.; Maas, A.C.S.; Martins, M.A.; Pedrozo, A.R.; Araújo, R.M. \& Peracchi, A.L. 2016. Morcegos em área de restinga de unidade de conservação no estado do Rio de Janeiro, sudeste do Brasil. Neotropical Biology and Conservation, 11:31-37.

Hay, J.D.; Lacerda, L.D. \& Tan, A.L. 1981. Soil cation increase in a tropical sand dune ecosystem due to a terrestrial bromeliad. Ecology, 62(5): 1392-1395.

Instituto Brasileiro de Geografia e Estatística (IBGE). 2012. Manual técnico da vegetação Brasileira. Rio de Janeiro, IBGE.

Kalko, E.K.V. \& Handley, C.0. 2001. Neotropical bats in the canopy: diversity, community structure, and implications for conservation. Plant Ecology, 153(1-2): 319-333.

Kalko, E.K.V.; Handley, C.O. \& Handley, D. 1996. Organization, diversity, and long-term dynamics of a Neotropical bat community. In: Cody, M.L. \& Smallwood, J.A. Long-term studies of vertebrate communities. New York, Academic Press. p. 503-553.

Larsen, R.J.; Boegler, K.A.; Genoways, H.H.; Masefield, W.P.; Kirsch, R.A. \& Pedersen, R.P. 2007. Mist netting bias, species accumulation curves, and the rediscovery of two bats on Montserrat (Lesser Antilles). Acta Chiropterologica, 9(2): 423-435.

Luz, J.L.; Costa, L.M.; Lourenço, E.C.; Gomes, L.A.C. \& Esbérard, C.E.L. 2009. Bats from the restinga of Praia das Neves, state of Espírito Santo, Southeastern Brazil. Check List, 5(2): 364-369.

Luz, J.L.; Mangolin, R.; Esbérard, C.E.L. \& Bergallo, H.G. 2011. Morcegos (Chiroptera) capturados em lagoas do Parque Nacional da Restinga de Jurubatiba, Rio de Janeiro, Brasil. Biota Neotropical, 11: 161-168.

Mikalauskas, J.S. 2005. Morcegos. In: Carvalho, C.M. \& Vilar, J.C. Parque Nacional Serra de Itabaiana: levantamento da biota. IBAMA, Aracaju, UFS, São Cristóvão, 93-103.

Mikich, S.B. 2002. A dieta dos morcegos frugivoros (Mammalia, Chiroptera, Phyllostomidae) de um pequeno remanescente de Floresta Estacional Semidecidual do sul do Brasil. Revista Brasileira de Zoologia, 19(1): 239-249.

Nogueira, M.R.; Mazurec, A.P. \& Peracchi, A.L. 2010. Morcegos em restingas: lista anotada e dados adicionais para o Norte Fluminense, sudeste do Brasil (Mammalia, Chiroptera). In: Pessôa, L.M.; Tavares, W.C. \& Siciliano,
S. Mamiferos das Restingas e Manguezais do Brasil. Rio de Janeiro, Sociedade Brasileira de Mastozoologia. p. 75-93.

Oprea, M.; Esbérard, C.E.L.; Vieira, T.B.; Mendes, P.; Pimenta, V.T.; Brito, D. \& Ditchfield, A.D. 2009. Bat community species richness and composition in a restinga protected area in Southeastern Brazil. Brazilian Journal of Biology, 69(4): 1073-1079.

Passos, F.C.; Silva, W.R.; Pedro, W.A. \& Bonin, M.R. 2003. Frugivoria em morcegos (Mammalia, Chiroptera) no Parque Estadual Intervales, sudeste do Brasil. Revista Brasileira de Zoologia, 20(3):511-517.

Peracchi, A.L. \& Lima, I.P. 2017. Chave dicotômica para as espécies de morcegos que ocorrem no Brasil. In: Reis, N.R.; Peracchi, A.L.; Batista, C.B.; Lima, I.P. \& Pereira, A.D. História Natural dos Morcegos Brasileiros. Rio de Janeiro, Technical Books Editora. p. 21-62.

Pessôa, L.M.; Tavares, W.C. \& Gonçalves, P.R. 2010. Mamíferos das Restingas do macrocompartilhamento litorâneo da Bacia de Campos, Rio de Janeiro. In: Pessôa, L.M.; Tavares, W.C. \& Siciliano, S. Mamíferos de Restingas e Manguezais do Brasil. Rio de Janeiro, Sociedade Brasileira de Mastozoologia. p. 11-16.

Rizzini, C.T. 1997. Tratado de fitogeografia do Brasil: aspectos ecológicos, sociológicos e florísticos. Rio de Janeiro, Âmbito Cultural.

Rocha, C.F.D.; Van Sluys, M.; Bergallo, H.G. \& Alves, M.A.S. 2005. Endemicand threatened tetrapods in the restingas of the biodiversity corridors of Serra do Mar and of the Central da Mata Atlântica in eastern Brazil. Brazilian Journal of Biology, 65: 159-168.

Rocha, P.A.; Feijó, J.A.; Mikalauskas, J.S.; Gouveia, S.F.; Silveira, V.V. \& Peracchi, A.L. 2010. Morcegos (Mammalia, Chiroptera) capturados no Campus da Universidade Federal de Sergipe, com oito novos registros para o estado. Biota Neotropica, 10: 1-6.

Rocha, P.A.; Tavares, V.C. Pedroso, M.A.; Beltrão-Mendes, R.; Ruiz-Esparza, J. \& Ferrari, S.F. 2018a. First record of Dermanura anderseni (Chiroptera, Phyllostomidae) for the Atlantic Forest. Mammalia, 82(4): 388-392.

Rocha, P.A.; Ruiz-Esparza, J. \& Ferrari, S.F. 2018b. Differences in the structure of the bat community between a cloud forest refuge and a surrounding semi-arid Caatinga scrubland in the northeastern Brazil. Journal of Arid Environments, 151: 41-48.

Rocha, P.A.; Ruiz-Esparza, J.; Beltrão-Mendes, R.; Moura, V.S.; Albuquerque, N.; Terra, R.F.C.; Mendonca, L.M.C.; Silvestre, S.M. \& Ferrari, S.F. 2017. Rapid surveys as a key tool for the inventory of the bat fauna of Brazil: new records for the coastal restinga. Neotropical Biology and Conservation, 12: 91-99.

Rocha, P.A.; Ruiz-Esparza, J.; Ribeiro, A.S. \& Ferrari, S.F. 2015. Species diversity and seasonal variation in the composition of a bat community in the semi-arid brazilian caatinga. Acta Scientiarum Biological Sciences, 37(2): 197-203.

Silva, S.M. 1999. Diagnósticos das restingas do Brasil. In: Workshop de avaliação e ações prioritárias para conservação da biodiversidade da zona costeira e marinha. Anais. Porto Seguro. p. 1-30.

Silveira-Neto, S.0.; Nakano, D. \& Nova, N.A.V. 1976. Manual de ecologia dos insetos. São Paulo, Ceres.

Simmons, N \& Voss, R.S. 1998. The mammals of Paracou, French Guiana, a Neotropical lowland rainforest fauna. Bulletin of the American Museum of Natural History, 237: 1-219.

Soares, F.A.M.; Daher, M.; Perrelli, R.; Moreno, J.A.T. \& Ferrari, S.F. 2018. Note on bats (Mammalia, Chiroptera) in a Restinga area of Rio Grande do Norte, Brazil. Pesquisa e Ensino em Ciências Exatas e da Natureza, 2: 17-22.

Straube, F.C. \& Bianconi, G.V. 2002. Sobre a grandeza e a unidade utilizada para estimar esforço de captura com utilização de redes de neblina. Chiroptera Neotropical, 8(1-2): 150-152. 


\section{APPENDIX}

Vouchers deposited in the Coleção de Mamíferos da Universidade Federal de Sergipe (CMUFS): Artibeus lituratus CMUFS 0294 o'; Artibeus obscurus CMUFS 0253, 0285 ơ; Carollia perspicillata CMUFS 0257, 0286, 0293, 0295 9, 0251, 0252, 0255, 0290, 0297 ơ; Dermanura cinerea CMUFS 0292 \%, 0284 o'; Glossophaga soricina CMUFS 0287 \%, 0289 ơ; Lophostoma brasiliense 0250 \%; Myotis lavali CMUFS 0249, 0258 \&; Myotis riparius 0291 ơ; Phyllostomus discolor CMUFS 0288 \&, Platyrrhinus lineatus CMUFS 0254 ; Sturnira lilium CMUFS 0296 \%. 